\title{
Custom and Belief in the Icelandic Sagas.
}

\section{Winifred Faraday}

To cite this article: L. Winifred Faraday (1906) Custom and Belief in the Icelandic Sagas., Folklore, 17:4, 387-426, DOI: 10.1080/0015587X.1906.9719746

To link to this article: http://dx.doi.org/10.1080/0015587X.1906.9719746

曲 Published online: 14 Feb 2012.

Submit your article to this journal $2 \pi$

Џ Article views: 6

Q View related articles $\sqsubset$ 


\section{CUSTOM AND BELIEF IN THE ICELANDIC SAGAS.}

gY I. WINITRED FARADAY.

(Read at Meeting, 20th June, 1906.)

ENQUIRY into Scandinavian paganism has hitherto been mainly directed to its mythological side, where the sources are so full and so alluring. The ritual and customs of the North have been left comparatively untouched, although it might be supposed that the Icelandic family and historical sagas would present a considerable field for such enquiry. Vigfússon and Powell attempted a collection of the material. But this is incomplete, and the material unclassified and for the most part without comment. Nor is any use made of the materials in the Kings' Lives: nor any attempt at enquiry into origins. Large portions of different sagas are rejected as spurious or late, without regard to their possible value as tradition, even if interpolated. As regards other work done on the subject, attention has been fixed almost exclusively on the picturesque hierarchy of Asgard and the Valhalla myth, the formularised religion of the Viking age; and the older strata of belief there and elsewhere evident have been neglected. Among Continental scholars especially there has been a tendency unduly to exalt the authority of Saxo, which also darkens counsel. Saxo's testimony may serve to confirm a better tradition, but it is worthless unless confirmed by it; it is impossible for instance 


\section{Custom and Belief in Icelandic Sagas.}

to regard for a moment the evidence of the bigoted Danish monk where it differs from that of Snorri, an honest and intelligent witness who knew his subject and had no parti pris. Another practice from which the subject has suffered is that of ascribing to Celtic influence everything interesting in Norse sources which touches on the supernatural.

The materials for the present study are collected chiefly from those Icelandic sagas which deal with the time before the establishment of Christianity in Iceland in the year 1000, and from the Lives of the Kings of Norway, as far as the death of Olaf Tryggvason in the same year, in the Heimskringla; with occasional reference to the Prose Edda where this serves to throw light on the other sources. In the Icelandic family sagas the references are scattered. The saga-writers are sparing of detail, and mention nothing that does not actually bear on some feature of the story: there is also a general vagueness in the matter of dates and seasons. The references are arranged as far as possible in order of date of occurrence, which can usually be approximately fixed by reference to genealogies; the date of occurrence being naturally of importance, where the question is of the growth or decay of a custom.

The present literary form in which the sagas are cast dates in the case of the greatest sagas to the thirteenth century. The longer sagas are compilations from a number of smaller ones; in the case of Njala, Laxdala and Egla, the compilation is carefully done, Laxdxla especially arranging its material with considerable attention to artistic effect; the other two are more to be depended on, therefore, in matters of detail. In Eyrbyggja there is little attempt to present an artistic whole. The shorter sagas which supplied the material for these must, even in their written form, have been composed a century earlier; and to the twelfth century at latest 
the present form of Kormaks Saga must be ascribed; Hartar Saga, Hoensa-thoris Saga, Vapnfirtinga and Hezrarviga also give evidence from style of early date, and, together with Kormaks Saga, of having existed orally before the period of the saga writing, that is before the close of the eleventh century. The accounts in Floamanna of the difficulties and hardships of early settlers in Greenland are too graphic not to be authentic. The Waterdale Saga is an old story worked over, and the same is true of Thorskfirvinga. Gisla is a beautifully told story belonging to the best period of saga-composition, though, as in Viga-Glum's Saga, the subject is old. Such stories as Thorstein the White, Thorstein Hall of Side's Son, and Thidrandi, are examples of the small sagas which provided the material from which longer compilations were made. Of the two versions of the story of Droplaug's sons (Fljotsdala), one is old, the other a very diffuse and inferior late composition. The Kings' Lives were compiled by Snorri in the thirteenth century from older versions; but his honesty, learning, and complete absence of bias make his testimony of great value. In all the sagas any approach to Christian prejudice is easily recognised, the more so from its rarity.

\section{THE GODS.}

The Asgard hierarchy, as systematised during the Viking age, contains, according to Snorri, thirty or thirtyone gods and goddesses. Some of these are merely personified epithets, and the list can be reduced to about twenty who have a real existence in myth: Odin, the chief, a wind or storm-god; Thor, the thunder-god; Baldr, a tree-spirit; Njörd, Frey, and Freyja, agricultural deities; Tyr, an ancient sky-god; Loki, a primitive firespirit; Frigg, the Hera of the Norse hierarchy; Heimdal and Hoeni, whose characters are not made clear; Gefjon, 


\section{Custom and Belief in Icelandic Sagas.}

apparently an ocean-goddess; Idun, a doublet, probably tribal, of Freyja; Höd; and half-a-dozen others not distinctly characterised, who may be tribal deities, or heroes elevated into the hierarchy. Of the whole list only two, Thor and Frey, are ever mentioned in the sagas as receiving actual worship. The references are as follows, arranged chronologically so far as is possible: Thor.

I. (Thorskfirtinga, 890): Thorolf Mostrarskegg was a great sacrificer and believed in Thor. When he reached Iceland, he sacrificed that Thor might send his pillars to land, and gave his son for it. This is explained in Eyrbyggja as meaning dedication, not sacrifice: "Thorolf gave his son to Thor, and called him Thorstein."

2. Landnama records of the same settler: "He took down his temple (i.e. in Norway) and took with him most of the wood, and the earth under the altar that Thor had sat on. He threw overboard the pillars that had stood in the temple. Thor was carved on one." He named the promontory where the pillars landed Thorsness, and made it sanctuary. He built a great temple there, and he and his descendants made strict laws to preserve the sanctity of the place. The carrying of the temple-pillars is a common incident in records of the settlement; the taking of the holy earth, like the "two mules' burden of earth" which Naaman took back to Syria, is recorded nowhere else. It may be a recognition of the local character of the god, though "the altar that Thor had sat on" looks like a survival of the throne-altar carried with them by settlers.

3. Helgi the Thin, another settler, had become Christian in the Hebrides; "he believed in Christ but vowed to Thor in great matters" (Svarfdala, 890). 


\section{Custom and Belief in Icelandic Sagas, 391}

4 Örlyg and Koll went out together, from Ireland. Örlyg was Christian, "but Koll vowed to Thor." They got separated in the storm, but both came to land (Landnama, about 890).

5. (Floamanna Saga, 990). Thorgils Örrabeinsstjúpr Thbroarson had been a devotee of Thor, but became Christian some years before the establishment of Christianity in Iceland. Thor appeared to him in dreams and threatened him. One night a "home-boar" died (i.c. a boar which had grazed in the home enclosures); he had it buried by some fences, and let no one eat of it. Another night an old ox died. Then Thorgils watched; next morning he was blue all over, so that people thought he and Thor must have met. Before starting on his journey to Greenland he dreamt again, and Thor, "big and red-bearded," threatened him with a bad voyage. When bad weather came, many wanted to sacrifice to Thor, but Thorgils forbade it. During the voyage he remembered having once dedicated a calf to Thor; the calf, now a full-grown ox, was on the ship, and he decided to throw it overboard. A woman of the company became angry and begged that they might have it for food: "No wonder things go ill, when Thor is so much insulted ;" but Thorgils refused.

6. (Gurnlaugs Saga, 1003). In Norway, Thord vowed to Thor for victory over Gunnlaug in a wrestling match.

7. (Thorfinn Karlsefni's Saga, 1007). The Christian settlers in Greenland became very short of food, and answer to their prayers did not come as quickly as they wished. Thorhall made a poem in honour of Thor, and was rewarded by a whale, of unknown species. The whole party, 


\section{Custom and Belief in Icelandic Sagas.}

- however, became ill after eating of it; and when they learnt where it had come from, they threw away what was left.

8. (Njala, 990). He is mentioned as standing with Thorgerd Hölgabrír and Irpa in the temple of Earl Hakon and Gudbrand of Dale, in Norway. Fljotsdala (990) mentions him with Frey, Frigg, and Freyja, in Bersi's temple, in Iceland, but the style of the passage is late, and an older version of the same incident names no special gods.

Frey--More than one reference to Frey seems to point to his being originally a tribal god of the Swedes. Whatever his origin was, he found wide acceptance, and was, with the possible exception of Thor, the favourite Icelandic deity, so far as can be judged from the material. More than one Icelander is famous under the title of Freys-priest; eg. Hrafnkel Freysgori (about 946) and Thord Freysgori (about 970).

1. (Hrafnkel Freysgoti's Saga, 946). Hrafnkel Freysgoti liked no god more than Frey. He shared his best treasures with him, and gave him half the horse Frey-faxi, vowing to kill anyone who rode it. He kept his oath; but discarded his favourite deity when the other chiefs of the district destroyed his temple in vengeance for the slain Einar.

2. (Waterdale Saga, 954). Brand put his trust in his horse Frey-faxi.

3. V'ga-Glim's Saga (957). Thorkell the Tall went to Frey's temple and led thither an old ox, and said, "Frey, who hast long been my chief trust, and hast received many gifts from me and well rewarded them, I give thee this ox, that Glúm may go from Thvera as unwillingly as I now go. Give me some sign whether thou accept or not." The ox fell dead, and Thorkell went away happy. The sequel took place some thirty years later. 
Custom and Belief in Icelandic Sagas. 393

Glúm dreamt that many men came to Thvéra' to meet Frey. They said to him, "We are thy dead kin, and we ask Frey that thou be not driven from Thvera, but he answers proudly and angrily, and remembers now Thorkell the Tall's ox gift." Glúm never thought so well of Frey after that.

4. (Gisli Surssori's Saga, 964). Thorgrim meant to have an autumn-feast at the Winter-Nights, to welcome the winter and to sacrifice to Frey. In the same saga it is said of Thorgrim that "snow never remained, and it never froze, to the south of his howe, because Frey protected him on account of the sacrifices."

5. (Waterdale Saga, 872). Ingimund had a silver lot in his purse, with Frey's image on. It disappeared from his purse, and was seen by the Finns in their trance at the place in Iceland where he afterwards settled. He said, "Frey will let his image come where he wishes his seat of honour."

There are a few other references to gods, where there is no record of actual sacrifice.

I. (Hallfred's Saga, 996.) A crew of Icelanders detained by Olaf Tryggvason vowed "to give Frey much money if they got to Sweden, Thor or Odin if they got to Iceland; but if they did not get away from Norway, the king should have his way." Similarly in the Laxdala, about the same time, Kjartan becomes Christian on the understanding that he will pay some worship to Thor next winter in Iceland.

2. (Gisla Saga, 958.) The form of the Foster-brother Oath called "all the gods to witness"; and in the Waterdale (935) those who failed to keep an appointment for the holmgang, or single-combat, were threatened with "the anger of the gods and the name of truce-breaker." Similarly, in the old 


\section{Custom and Belief in Icelandic Sagas.}

version of the incident of Droplaug's sons and Bersi's temple, Bersi attributes a storm to the anger of the gods because Helgi and his brother had gone solarsinnis (with the sun) round the temple, and had not announced by law the slaying of Tordyfil. In Vlga-Glúm's Saga, Glúm swears " to the Ás" (Thor) that he was not there when Thorvald Krob was slain. In Landnama the form of oath is by "Frey and Njöro and the almighty As."

These references sufficiently indicate a stage of religious development corresponding to that represented in Greece by the Homeric poems. The gods are not yet moral, but are the guardians of such rules of social order as are sufficiently fixed to be under their protection; as in Homer perjury and injuries done to parents are punished by divine anger.

The matter-of-fact attitude of the Icelanders to the gods (instance the open disapproval expressed by devotees like Glúm and Hrafnkell when they did not receive adequate support from the deities of their special worship) does not necessarily prove that the religion was decaying. Their irreverence, like that of Homer's heroes, is natural to a stage of development in which men have outgrown the blind fears and ignorance of the primitive savage, and have acquired some command over nature, but have not yet attained the more spiritual conceptions represented by Greek tragedy. Norse religion was killed by Christianity before it reached that stage. That it had sufficient vitality to make a struggle for existence is repeatedly witnessed to in the sagas; for example, in Laxdala: "There was a change of faith in Norway; men took to it very unequally; they said the weather was bad because of the king's new faith"; and again, when the establishment of the new faith in Iceland was attempted, "many went against it ; it was hard to .keep the peace between heathen and Christian." Hjalti, an 


\section{Custom and Belief in Icelandic Sagas. 395}

Icelander who preached the new faith, was outlawed for blasphemy.

What looks like a curious tendency to free-thinking appears, however, in Thorstein in the Waterdale (954), who believed in "him who made the sun, whoever he be, for him I think mightiest"; and in Thorkell Máni, a Lawman of about 970, who adopted "the god who made the sun," and when his death was approaching had himself carried outside that he might die in the sunlight.

It may seem strange that Odin, the head of the Asgard system, is not named in the sagas as receiving sacrifice, and other omissions, Frigg and Freyja, for example, are equally striking; though all three names are common enough in the kennings of the poets Nothing can of course be argued from mere omission, though in the case of Balder it has been used as an argument telling against his divinity. In dealing with Scandinavian religion the argument is especially fallacious: the sagawriters are always economical of detail, and, as they were not writing histories of ritual and mythology, sacrifices would only be mentioned as they happened to relate to the fortunes of the story. Further, the written form of the sagas is not contemporary, and Odin's omission may be accounted for by his becoming, as supreme god and the most highly organised Scandinavian deity, an object of special hostility to missionaries-an argument applied with much force by Mr. Nutt to Irish mythology. A Scandinavian example of this missionary zeal is offered by Saxo's violent attacks on Frigg, to be explained by the strength of her influence as a rival to the Virgin Mary.

In the references to Thor it will be noticed how many of his devotees bear his name as part of theirs, which may be accounted for either by their actual dedication to him, as in the case of Thorstein Thorolfsson, or simply by his popularity. 


\section{Custom and Belief in Icelandic Sagas.}

Another suggestive point is the custom of keeping sacro-sanct animals, which may be compared to the cattle sacred to Artemis in Phocis, and the swine consecrated to Aphrodite at Hierapolis. Hrafnkel, and by inference Faxa-Brand, each kept a horse sacred to Frey, and Thorkell the Tall devoted an ox to him. In Floamanna we have a calf which had been dedicated to Thor, and it seems probable that the "home-boar" and the old ox killed by divine visitation in the same saga were also the property of the god, as Thorgils makes the same prohibition against their being used for food as later in the case of the calf. Possibly Thor's special claim against Thorgils himself was justified by the latter's name.

A goddess mentioned who is not one of the Asgard divinities is the sea-goddess Rán, referred to in an episode in Eyrbyggja (after the year 1000). Thorodd and his companions were drowned at sea; the ship was fished up, but the bodies could not be found. Men were drinking the Yule-ale, but they turned it into a wake. On the first evening of the wake Thorodd and all his companions came in. Everyone welcomed them, and thought their coming good, because "it was held true that men were welcomed by Rán if sea-dead men visited their wake; for little had been lost of heathendom, though men were christened and called Christian." They spoke to none, but came every evening and sat by the fire. Everyone thought the haunting would cease when the wake was finished, but it did not. This is a testimony to the tenacity of the old beliefs, to the vitality of those vague and primitive forms which existed in the minds of the common people and were never embodied in any system; just as there were nature-divinities in Greece who were never admitted into the Olympic circle. The late Dr. Abbott notices the vague and fluctuating nature of the Homeric sea-gods, "creatures which cannot easily be brought within the limits of human life," and which 
were not among the Olympians, though Poseidon is introduced as the brother of Zeus; they had something of the vagueness and mystery of the sea, and were not readily brought within a system. An oath by "Rán and the Regin" is given in Ölkofra Thattr.

\section{HERO-WORSHIP AND UNDERWORLD DEITIES.}

That spirits connected with rites for the dead were worshipped among the Scandinavians down to the very close of the pagan time, is clear from the sagas, although the evidences are not abundant. The question is closely bound up with the subject of burial customs; these I shall give in their turn, but in the meantime a general summary of the practice and belief may be given here.

It is clear that primitive ideas of continued existence in the howe remained in full force right down to Christian times. This assertion rests on the following:

1. Burial in commanding positions (e.g. headlands).

2. Placing treasure, ships, tools, weapons, slaves, in the burial mound.

3. The belief that the dead man was affected by the outward condition of his howe.

4. The belief that men "died into the fell"

5. The extremely prevalent belief in ghosts; that is, in the continued activity of the dead, which is not always malignant: Klaufi helps his friends to avenge him (Svarfdala, 960); Thorgunna comes back and prepares meals, and no one suffers from them (Eyrbyggja, 993).

6. The appearance in dreams of dead kindred.

Where these ideas exist, we should expect to find traces of local hero-cults, and of the propitiation of underworld divinities.

The belief in certain supernatural beings closely connected with the individual man living and dead, appears in the sagas in the form of female spirits who follow 


\section{Custom and Belief in Icelandic Sagas.}

and protect a man during his life, announce to him his death, and in some way represent him after death, extending help and protection to his descendants. They are not the souls of the dead, but nameless divinities, the life-principle of man or woman. The names hamingja and fylgja (for there seems to be no difference between the two) are both applied to them. Hamingja is a derivative of hamr (a shape), and fylgja of the verb fylgja (to follow). One or two examples will suffice:

I. (Thorskfirtinga, 930.) Kjarlak tells Steinolf "Thy fylgjur cannot stand against Thori's fylg jur."

2. (Viga-Glúm's Saga, 950.) Glúm in a dream saw a woman of giant size coming to Thvera. When he woke, he said, "I think Vigfus, my mother's father, must be dead, and the woman will have been his hamingja, who walked higher than the mountains ; and his hamingja will seek an abidingplace where I am."

3. (Hallfred's Saga, 1007.) On Hallfred's last voyage, a woman, tall and clad in mail, followed the ship. He said it was his fylgju kona, and said to her, "All is over between us." She asked his elder son, Thorvald, to take her; he refused, but the younger, Hallfred, consented, and to him Hallfred gave his sword.

4. (Thorstein Hall of Side's Son's Saga, 1050) Thorstein dreamed that three women came to him, on three successive nights. Each night a different one spoke first, and warned him of his death through the treachery of his slave Gilli. The last night they asked to whom they should turn after his day, and he said, "To my son Magnus."

5. (Olaf Tryggvason's Saga, about 997.) Thorkell the Seer, of Horrgsland, was staying with his friend Hall of Side for the Autumn Feast. One night the latter's son, Thidrandi, was summoned out of 
the house by mysterious sounds. Nine women in black, with drawn swords, came from the north, and nine in white on white horses from the south. Thidrandi did not return to the house, and at last they went out. It was moonlight and frosty weather. He was found dying, and died next morning, after telling what had happened. He was laid in the howe in the ancient way. Thorkell's explanation was, "I think the women were the fylgjur of you and your kindred; I think a change of faith is coming . . . and that your DLsir, who have followed this faith, must have known beforchand of the change, and also that you and your kin will give them up, and they will not be content to have no tribute from you. ... . The better Disir must have wanted to help him." Some time after this incident, Thorkell was heard laughing to himself, and explained that he saw the hillsides opening, * and every living creature great and small flitting, bag and baggage."

About this last reference there are several points worthy of notice (1) The Disir, of whom I shall have to speak again, are here definitely identified with the fylgjur who represent the dead. (2) The divinities who take their flight before the new order, are earth-deities, creatures of the fairy-hill. (3) Thorkell's home is Hörgsland, taking its name from the hörg, a significant word wherever it occurs in place-names. The hörg is an openair altar or cairn, and wherever it occurs, as distinguished from the hof or temple which belongs to the more defined Asgard divinities, it suggests this kind of worship. (4) There may also be significance in the fact that Thorkell was Spamarr or Seer, which seems reminiscent of the divination commonly practised in connexion with underworld rites in other religions.

There seems then no doubt that the Dtsablbt or 
400 Custom and Belief in Icelandic Sagas.

sacrifice to the $D$ tsir which is mentioned occasionally in the sagas, was a sacrifice to spiritual powers of a vague kind, not yet grown into individual deities; female, and representing in some way the underworld of the dead. Their sex is a mark of antiquity; that and their relation to the dead and the underworld being fully accounted for by the mystical character attaching to the offices performed by women, and the fear of them, among savages generally. The Disablbt has sometimes been described as connected with the worship of Freyja, and taking place at midwinter, but there is no saga-authority for this. There is no recorded case of a Disablot in Iceland, but there are cases in Norway:

I. Heimskringla (Ynglinga Saga). King Adils was at a Disablot ; and as he rode round the hall, his horse stumbled and fell, and he was thrown on his head, and his skull was split (mythical).

2. (Egil's Saga, 923.) King Eirik and Gunnhild came to Atley, and Bard had prepared a feast for them, and there was to be a Disablót. (The context proves that this was in the autumn.)

We cannot decide whether there is any significance in the fact that it was at the Winter-Nights' Feast that the Disir killed Thidrandi. The Greek and Roman festivals of the dead were in spring, to keep off evil influences from the crops; but on the other hand, the Christian ones come not at seedtime but after harvest, and so far as it goes, the evidence points to the same season for the Scandinavian service of the dead.

III. Burial Customs aNd Hero-Cults.

There are two beliefs about the state of the dead evident in the sagas, existing side by side, often appearing in the same instance, though mutually inconsistent. These are life in the howe or burial-mound, and the journey to Valhalla. It is natural that inconsistent notions should 
Custom and Belief in Icelandic Sagas. 40I

flourish side by side, on subjects of which we know nothing, especially in the case of death, where loss and affection keep the mind restless. The Valhalla notion belongs to the systematised religion of the Viking age; yet it is clear that the primitive idea of continued existence in the howe, and of a man's wanting the same things after death as before it, continued in full force. He is buried in his clothes and weapons; often in a ship; once with his horse and tools; once with a slave; often with treasure, though this custom, as was natural, fell into decay. The following are the chief instances:

I. (Egils Saga, 877.) They did with Thorolf's body according to custom, and put up a memorial stone after him. (In Norway.)

First Quarter of the roth Century.

2. (Svarfdala, before 910.) Thorstein took Thorolf's body to Sweden, and borrowed an earl's hall to drink the arval. He laid Thorolf in the howe with much money to honour him, and the feast was held three nights, according to custom.

3. (Ib.) Thorstein put his father Thorgnyr in the howe, and much money.

4 (Landnama) Geirmund was laid in a ship in a wood not far from the house.

5. (Egil's Saga, 925.) Egil took up Thorolf's body and washed and prepared it according to custom. He was put in the grave with all his weapons and clothes, and Egil put a gold ring on each hand. Then they built it up with stones, and sprinkled it with earth.

6. (Floamanna, 926.) Atli was howed as was then the custom.

7. (Reykdala, c. 925.) Eyvind was howed at Helgastar.

8. (Landnama, c 925.) Hafnar-Orm was howed on the headland in front of the homestead at Hafn, where he first came to land. 
402 Custom and Belief in Icelandic Sagas.

Second Quarter.

'9. (Egil's Saga, 933.) A howe was made for Harald Harfagr at Haugasund.

10. (Ib., 934) Egil laid his father Skallagrim in a ship and rowed out to Digraness. There a howe was made, and Skallagrim laid in with his horse and weapons and smith's tools. It is not told that movable property was laid with him in the howe.

11. (Waterdale Saga, 935.) Ingimund was laid in a boat from the ship Stigandi, and everything done as honourably as was the custom with men of rank.

12. (Heimskringla, c. 950.) Hakon the Good had the dead men laid in ships, which he drew up from the shore to the battlefield.

Last Quarter.

13. (Egil's Saga, 960.) Skallagrim's howe was opened, and Egil's son Bð̋var laid in.

I4 (Gisli's Saga, 963.) Vestein was laid in the howe according to custom. His murderer Thorgrim bound on the hell-shoes, saying "It is customary when men have to walk to Valhalla."

I5. (I6., 964) Thorgrim was laid in a ship, and the howe made in the old way; before it was closed, his murderer Gisli put a stone in the boat as an anchor.

16. (Svarfdala, 965.) Karl and the Eastmen were carried up to Karl's River, and there laid in a ship, and much treasure with them.

17. (Gisli's Saga, 978.) Thorkell was howed in the old way.

18. (Laxdala, 972.) Höskuld was howed honourably. Little money was put in the howe with him.

19. (Egil's Saga, 982.) A howe was made and Egil laid in with his weapons and clothes. 


\section{Custom and Belief in Icelandic Sagas. 403}

20. (Eyrbyggja, 993.) Arnkell was laid in a howe by the sea, as big as a stackyard.

21. (Fljotsdala, 998.) Kari was carried on a shield to Höfti; and a howe thrown up after him.

22. (Ib.) A howe was made, and there Helgi and Thorkell were howed. On the other hand, others who fell were simply jartatir (earthed or buried) where they fell.

Women were also howed sometimes Aud the Wealthy, about the year 900, was laid in the howe in a ship, as befitted so notable a traveller, and much money with her, after a three days' feast (Laxdala); according to Landnama, her howe was on the shore below high water mark, that she might not be in unhallowed ground, as she was Christian. Droplaug's mother Arneio (Fljbtsdala) was "howed outside the garr"; and Thorstein laid his mother Ingibjorg in the howe beside her husband (Svarfdala).

The belief that a dead man would still want the things he had wanted in life is fully illustrated in these passages. It is combined no doubt with the idea of a journey to Valhalla, in the practice of ship-burial; and it further appears in two undoubted survivals from former slavesacrifice, both in Landinama.

1. When Asmund died during the settlement-years in Iceland, he was buried in a ship in a howe, with a thrall "who slew himself because he would not live after Asmund." The chief, however, appeared in a dream to his kindred and complained that the thrall was annoying him, so the howe was opened and he was removed.

2. When Ingimund died during the same period, he was laid in a boat and buried as honourably as was the custom with men of rank. One friend killed himself, sending a message to another to do likewise, because "there is no life for the friends of Ingimund." 


\section{Custom and Belief in Icelandic Sagas.}

The dead were affected by the condition of their burialmounds. It is noted in Landnama that "Einar's howe was ever green winter and summer," and in Gisla that Thorgrim's howe never froze because of the favour of Frey. Asolf, in Landrama, appeared after death to his friends in a dream, to complain because a cow-girl wiped her feet on his howe.

These instances all point to the continued consciousness of the dead after burial. A step further is reached in the belief of the Thorsnesinga that they would "die into" Holy Fell, which is explained exactly by what is said in Eyrbyggja of Thorolf: "He thought he would go there when he died, and all his kinsmen on the ness," (Eyrbyggja and Landnama, 890). A similar belief was held by the kindred of Aud the Wealthy, who was a Christian and put up a cross on a hill. Her kinsmen made a howe there and sacrificed; "they thought they would die into the hills" (Landrama, 900). "When Svan, son of Björn of Bjarnarfjört, was drowned, "he was seen to go into the fell " (Landnama, 940). A still clearer case of the belief in a continued life in the burial-mound like that of the Tuatha Dé, or of Holda in the Hörselberg, occurs in Eyrbyggja (938). Thorstein was drowned in the autumn on a fishing cruise. Before the news was known, his shepherd saw the fell open to the north. There were great fires inside, and great noise and clatter of horns; he tried to catch some of the words, and heard a greeting spoken to Thorstein and his comrades, and a voice said that he was to sit in the high seat opposite to his father (that Thorolf Mostrarskegg who had believed that he and his kin would "die into the fell" and who as a devotee of Thor had dedicated this son to his favourite god).

When Gunnar of Hlixarendi was slain, his mother had him buried in a sitting posture, doubtless that he might not sleep till avenged. He was heard speaking in the 


\section{Custom and Belief in Icelandic Sagas. 405}

howe, and his son Högni and Skarpherinn Njalsson saw the howe open, and lights inside, and Gunnar turning round to look at the moon (Njdila, 990).

Where such beliefs are held, hero-cults may be expected to flourish. In Gunnar we seem to have one in the making ; and another, in a more advanced stage, in Grim, great-great-grandfather of the settler Thorstein Solmundsson, to whom, according to Landrama, sacrifice was made after death because of his popularity. When TunguOdd was buried "where he could overlook the Tongue" (Hoensa-Thoris Saga, 988), and Hafnar-Orm on the headland in front of the homestead, it was possibly with the idea of their affording protection. The account of Hrapp's burial (Laxdala, about 970) illustrates the collision of the belief in the protecting power of the friendly dead with the natural fear of ghosts. At his own wish he was buried upright in the doorway, "that he might oversee the household," as a Greek hero was buried in the gateway, probably with the idea that he could prevent the entry of evil influences. But Hrapp walked, and he was first removed to another spot, and later dug up again and burned, the ashes being thrown out to sea.

A genuine hero-cult seems to appear in the worship of Thorgerd Hölgabrút or Hörgabrút. Njdla states that in the temple of Earl Hakon and Gudbrand of Dale there stood the figures of Thor, Thorgerd Hörgabrír, and Irpa ; and in Hartar Saga, Grimkell, wishing to enquire about the marriage luck of his daughter, went into the temple of Thorgerd Hörgabrúr. She promised favour to Thorbjörg, but not to Höro, his son, who had desecrated the grave of her brother Sóti and stolen his good gold ring. The other references to her are:

1. Snorri (Edda) calls her the daughter of Hölgi, king'of Halogaland: "they were both sacrificed to, and a howe was cast up to Holgi, one layer of gold or 
406 Custom and Belief in Icelandic Sagas.

silver (that was the sacrifice money) and one layer of earth and stones."

2. In the Jbmsvikinga Saga and the Jomsvikinga-drapa,. she is mentioned on board Earl Hákon's ship in the Jomsviking battle. She caused a great hailstorm, and an arrow seemed to fly from each of her fingers.

3. An anonymous Grammarian (about I140) says "a great woman died when Hoblgatróll died."

4 Saxo speaks of a Thora, bride to Helgi King of Halogaland.

He also tells a story, repeated in other sources, of a Thora, Helgi and their illegitimate daughter Yrsa, which Detter identifies with this one by means of an argument, more ingenious than convincing, that Yrsa, being baseborn might very well have been called Irpa. The only answer is, that she never is so called in any version of her story. The whole identification rests on similarity of names, which is usually futile, especially in Scandinavian. Saxo never suggests that the two pairs named by him Helgi and Thora were the same; there might have been a hundred so-named. It would be as reasonable to suggest that Njal's daughter Thorgerd and his son Helgi .were connected with this legend.

According to both Saxo and Snorri, Hölgi seems to be regarded as the eponymous hero of Halogaland. The etymology is not satisfactory, but the connexion with the North of Norway rests on better evidence than the philological, in the devotion of Earl Hakon to Thorgerd, the evidence for which is unimpeachable. Thorgerd is called both Hölgabrúr and Horgabrút, and it is uncertain which is right. "Holgi's Maiden" may have been turned into "Maid of the Cairn" because she was worshipped there, or "Maid of the Cairn," "Altar-bride," may have become "Hölgi's daughter." because she was so. It seems obvious that we have here the cult of a local hero and heroine like that of Cecrops and his daughters. Her behaviour in the 


\section{Custom and Belief in Icelandic Sagas. 407}

Jómsviking battle is just what would be expected of a local heroine. As to her being in Gudbrand's temple, her worship should really have been an open-air one, that of the hörg not the hof. But Njala is so careful of detail that one hesitates to reject anything, and it is quite likely that Earl Hakon, being an enthusiast, a kind of pagan revivalist, would introduce an image of his favourite beroine into his temple, among the gods.

Her place in an Icelandic temple, or indeed in Iceland at all, is more difficult to explain. Iceland was not her sphere of influence. Grimkell came from the Drontheim district to Iceland; and it is possible that Thorgerd may have become famous beyond her own locality, and indeed be on the way to becoming a goddess.... At all eyents, good luck in marriage is the kind of obvious human need that a hero or heroine would be expected to :help: in. Another explanation is that she miay have gained fame as the patroness of so famous a man as Earl Hakon, and bave been introduced into Harbar Saga by a writer in a Christian age who knew no distinction between one deity and another.

Hörg-worship in Iceland is proved by the occurrence of the word in place-names (e.g., Hörgsland in the story ef Thidrandi, inserted in Olaf Tryggrason's Saga; Horgardal, in Vtga-Glim's Saga).

Of the service of the dead there are a few traces. A remembrance goblet was drunk at the yule-feast at midvinter. In the holm-gang, or single-combat, it was the cistom of the victor to sacrifice a bull. Of this there are four saga-examples:

I. (Egils Saga, 938.) A bull was led there, big and old. It was called blbt-naut. He who had the victory was to kill it. Sometimes it was one bull, sometimes each who went to the holm had his own brought ... Egil leapt up quickly where the sacrifice-bull stood, grasped the lips with one 


\section{Custom and Belief in Icelandic Sagas.}

hand and the horn with the other, and turned it so that the feet turned up and the neck-bone broke.

2. (Kormak's Saga, 963.) After the holm-gang, Kormak saw where a bull stood, and killed it.

3. (Ib., 964) Kormak killed the sacrificial bullock according to custom.

4. (Heiðarolga Saga, 990.) After killing Halli, VigaStyrs had two bulls led home, and killed them, because it was the belief in those days that if it was so done the prosecution would come to nothing.

The origin of the sacrifice may have been propitiation either of the ghost of the slain enemy or of the spirits of the underworld, to prevent the ghost from haunting the spot. Later it must have been done as a mere convention, losing its original significance, as in the extracts from Kormak's Saga it was done though the other was not killed; in the earlier instance Kormak seems to kill the bull as a kind of claim for victory in 2 doubtful combat.

When, after the first holm-gang mentioned from Kormak's Saga, Thorvard's wound would not heal, the wise woman Thordis told him to obtain the bull killed by Kormak and pour the blood over "a hill near, where elves dwell, to give them a meal of fresh meat": a clear case of libation, whether the "elves" te the spirits of the dead, or earth-spirits, or both confused.

A survival of a similar rite in Christian dress seens to occur in a Greenland custom (Thorfinn Karlsefn's. Saga). When a man died in Greenland, he was usualy buried on the spot, in unconsecrated soil, with a state in the ground over him. When a priest came, the state was pulled up and holy water poured down the hole.

When Norse religion became systematised, confusicn of ideas naturally arose. In Ynglinga Saga both Odn and Frey are treated as ancestor-kings; both die, and 


\section{Custom and Belief in Icelandic Sagas. 409}

the general rites in the two cases seem to preserve the different characters of the two divinities. Odin, a heavengod, is burnt on the pile; Frey, apparently a god of arms and agriculture, is buried in a mound, into which money is put through three holes, and "peace and good seasons continued." This is rather to be regarded as a proof of the strength of hero-worship in the North, and of the belief in the old gods after the establishment of Christianity, than as evidence of the deification of a hero; it is not that the hero becomes a god, but that the god is confused with the hero. Dr. Warde Fowler notices the same tendency in Roman religion towards the end of the Republic, when Saturnus and Faunus figure as early kings of Latium. Mr. Chadwick seems to take the opposite view; several Continental scholars, relying largely on Saxo, conclude that Balder is a deified hero. Yet I do not know that any one has seriously adopted the same view of Odin, who is also a hero in Ynglinga and in Saxo. There is no indication that Frey and Odin were ever regarded as ancestor-kings in heathen times; and their being so regarded in sources composed in Christian times is rather due to an unwillingness to give up the old gods altogether.

On the other hand, a place is found in Valhalla for both the heroes and the vague female spirit-deities of the underworld, who seem to be combined with the Asgard hierarchy as the Einherjar and the Valkyries. The Einherjar, slain warriors who make up Odin's host, include dead heroes like Hakon the Good, Gunnar of Hlibarendi, Véstein Vesteinsson. The Valkyries, like the harpies, are wind or storm ghosts, who carry off men by a violent death; legend, by making them the attendants of Odin, the Wild Huntsman, marks their connexion with the storm-winds. I cannot accept Mr. Chadwick's suggestion that they originated as sacrificial priestesses, an idea which could hardly arise except in a sophisticated and literary fancy. In the case of the Norns, the Norse Fates, we have a 


\section{Custom and Belief in Icelandic Sagas.}

natural transition from the wise women who helped mothers and told the fortunes of children: from the existence of human beings with unnatural and uncanny gifts, goddesses were deduced, who protected mothers and children in the same way. In the story of Norna-Gest, for instance, it is impossible to decide whether the writer thought of the three sisters who prophesied the fate of the child as wise women or as goddesses : probably he himself hardly knew. To infer a goddess of death from a priestess is a less natural process.

In the same way, inconsistent ideas exist as to the state of the dead. In Njala, Gunnar lives on in the howe; yet when Högni is asked by his grandmother why he is taking his father's spear, his reply is "that he may have it to carry to Valhalla, and to bear at the weapon-thing." Hákon the Good (Heimskringla) is laid in a great mound with full armour and best clothes, and "they spoke over his grave in heathen fashion and wished him in Valhalla" Properly, mound-burial belongs to the idea that a hero lives on in the earth, and cremation to the notion of a journey, like Brynhild's Hell-ride. A confusion of ideas exists in the passage in Heimskringla, which states Odin's ordinance that men were to be burnt with their goods, and their ashes cast into the sea or buried: "thus everyone will come to Valhalla with the riches he had with him on the pile, and also enjoy what he himself buried." The notion of a journey only underlies the description of Hake's funeral, in the same source: he was laid wounded on a ship with the dead men and arms; the ship was taken out to sea and set on fire.

The idea of a dead man's journey to Valhalla in his ship, implied by his burial in it, must have arisen in the Viking age, and seems to be indicated by the contrast with the hell-shoes in Gisla. Véstein had the hell-shoes bound on because he would have to walk to Valhalla; Thorstein, a year later, was buried in a ship. There seems no obvious 
reason why the two burials should be different; the circumstances of the two murders were as nearly alike as Véstein's avenger could make them. If it had been a case of the Viking brother and the brother who stayed on the farm, the reason for distinction would be evident; but Véstein was a sea-goer. Possibly only a very rich man or one who was sole owner of his ship could afford to be buried in it; the saga does not say whether Véstein was sole or part owner of his.

The eyes of a dead man were supposed to have an evil influence; hence in two sagas we meet with unwillingness on the part of the living to pass in front of a corpse. In the case of Thorolf (Eyrbyggja, 986), this is easily understood, for he had been malicious and mischief-making in life. His son Arnkell bade no one pass in front of him till the corpse rites were done, and he was removed from the house through a hole broken in the wall behind his seat. The same precaution was taken after the death of Skallagrim (Egla, 934), though he had been a great chieftain.

Ghosts were not always malignant, though always dreaded; as a rule it was those who had been most troublesome alive who were malignant after death .These turn into a kind of vampire, like Glám in Gretti's Saga, and the above-named Thorolf in Eyrbyggja. In the case of the latter haunting, the cattle were "troll-ridden," the shepherd found dead, coal-black, with every bone broken: the sheep died; the birds who perched on the grave fell dead; thunderous noises were heard at night. But this ghost recognised the ties of kinship, for though he had quarrelled with his son Arnkell alive, dead he did no harm "where Arnkell was." He was reincarnated in a way curiously reminiscent of Irish legend. A ghost was usually laid in Iceland, by the digging up and burning of the body, the ashes being thrown out to sea. After Thorolf's ghost had been laid in this fashion, a cow belonging to his son 


\section{Custom and Belief in Icelandic Sagas.}

Arnkell used to go to the place where the fire had been, and it licked the stone where the ashes had lain. Soon afterwards it had an apple-gray calf which Arnkell named Glaesir. Arnkell's old fostermother repeatedly begged him to have it gestroyed, but in vain, until it had grown to a tremendous size and done much damage, when it finally disappeared. In Laxdala the ghost of Halbjörn, who was drowned and washed ashore, appeared in the form of a cow.

\section{Tomb-Treasures.}

The buried treasure, though, so far as cause and origin goes, it has already been discussed, deserves separate treatment as a fruitful producer of myth. Here myth can be seen in the making. At first treasure was always laid in the howe; then the custom decayed, as the natural desire of the son to inherit made itself felt. It was when the custom came into conflict with the desire, that the myths of cursed treasure and dragon guardians grew. The sacrosanctity of the burial-mound was only preserved by the belief that the treasure would carry no luck with it, and that supernatural terrors attended the violation of the howe: hence the supernatural lights, the fiery dragons, the berserks, to be met with in the mythical chapters of many sagas; hence also in myth the Sword of Angantyr and the treasure of Fafnir.

The decay of the custom is marked in the following examples:

I. (Svarfdala, 9ra) Thorolf was laid in the howe and some money to honour him.

2. (Ib.) Thorgnyr was laid in the howe, and much money.

3. (Laxdala, about 900.) Aud was laid in a ship in the howe, with much money.

4 (Egils Saga, 925.) Egil put a gold ring on each of Thorolf's hands. 


\section{Custom and Belief in Icelandic Sagas. $4^{\mathrm{r}} 3$}

5. (I6., 934) Skallagrim was howed ... It is not told that much money was laid with him. Egil inherited the lands and loose money.

6. (Ib., 965.) Karl and the Eastmen were buried, with much treasure. (As foreigners, they would have no heirs in Iceland to claim their money.)

7. (Laxdala, 972.) Höskuld was buried honourably; little money was put in the howe with him.

The transition is also marked in the reproach of Ingimund on his son's inactivity (Waterdale Saga, before the Settlement of Iceland): "In our day it was the custom with kings and earls, our peers, that they won for themselves fortune and fame; wealth was not counted as a heritage, nor would sons inherit from their fathers, but rather lay. their possessions in the howe with them."

These tomb-treasures were the natural prey of the adventurous :

1. (Landnama.) Korni was buried in Korni's howe; a man broke in and carried away his belt and ring.

2. (Ib.) Styrbjorn found a bag of money in a cairn and hid it.

3. (Ib.) Skeggi broke into Hrolf Kraki's howe, and got a sword and axe and much money.

4. (Floamanna, 946.) Later in the winter, some thralls broke open a howe for the money.

Examples of the terrors by which the howe was guarded against desecration occur repeatedly in the mythical chapters of sagas:

1. (Hoensa-Thori's Saga, 920) Thori broke open the howe of his father's brother, who directed him to a cave in Finmark where a viking and his sons guarded their treasure as fiery dragons.

2. (I6., 940.) Thori himself was not known to die; he disappeared with his treasure-chests, and is said to have lain on them and become a dragon.

3. (Harbar Saga, 965.) Hörd and his companions 


\section{I4 Custom and Belief in Icelandic Sagas.}

vowed one Yule to break open the howe of the Viking Soti before another Yule. Hord succeeded in the attempt, and stole Soti's ring and treasure chests, but the ghost laid a curse on the ring : it should bring death to its possessor.

\section{Divination.}

This was regularly practised among the Scandinavians. Men often "sacrificed to learn their fates" and the oracle seems to have been consulted both in special emergencies and at regular seasons. Harbar Saga (983) mentions an oracular stone, apparently like those at Sicyon and Megara: "Thorstein went into his blbthics (sacrificehouse), and fell down before the stone to, which he sacrificed, and spoke to it "; one who stood outside heard the stone sing in reply.

Divination was also a regular part of the templesacrifices. "There was a lot-bowl on the altar, and a lottwig with which the blood was to be sprinkled out of the bowl when the lot was called" (Eyrbyggja, 884). Heimskringla describes a Yule-feast when blood was sprinkled on the temple-walls and the people, and the flesh (of horses and other animals) eaten. That the Yuletide divination (like that of the Saturnalia) especially concerned the crops and the weather for the ensuing year, is suggested by a passage in Thorfinn Karlsefni's Saga, (100I): there was a feast in the winter-time, at which a wise woman, Thorbjörg, "the Little Sibyl," was present as chief guest. A special seat was prepared for her, with a cushion of hens' feathers, and special food (the hearts of all the animals slain), and she was questioned about the coming seasons. She would not conduct the incantations till she had slept, and must then have another woman to sing the spells for her. There is another example of midwinter divination in the Waterdale Saga (877). Ingjald had a feast in winter. An incantation was prepared * in the old 
way," that men might enquire after their fates. A wise Finn-woman was there, set high and honourably prepared for; each went up from his place to question her.

That divination should be practised chiefly by women is common and natural, considering their association with the rites of birth and death. Ynglinga Saga recognises the fact, accounting for 'it in another way: "such weakness and anxiety follows witcheraft, that it was not thought honourable for men to practise it, and therefore priestesses were brought up in the art." The "weakness and anxiety" suggests trances like the Pythia's; and one such is recorded of the three Finns consulted by Ingimund with reference to colonisation (Waterdale Saga) : he shut them up for three days, during which "their bodies became rigid, and they sent their souls on the errand."

Revelation by dreams is also common. In some cases the dream is symbolic; in others (as in the one already mentioned in V'ga-Glum's Saga), dead ancestors appear and make known the future. In Heimskringla, when Halfdan the Black consulted Thorleif the Wise as to how he should obtain dreams, the latter said that when he wanted revelation by dreams he slept in a pig-stye. This may possibly be a far-off survival of the practice of incubatio; or the reason may have been that close-air and semi-suffocation produce dreams, as clefts in the rock with mephitic vapours were favourite oracular seats in Greece. The sleep of the sibyl in Thorfinn Karlsefni's Saga is neither trance nor incubatio; but the elementary idea was the same. A similar notion underlies the incident recorded in Njdla and in Kristni Saga of the manner in which the change of faith was decided. The decision was entrusted to Thorgeir, who was a pagan. He lay down and drew his cloak over his head and lay all day and night, and another day just as long. A pagan would seek inspiration on the subject according to pagan means of divination; the heathen party may have stipulated for some such 


\section{Custom and Belief in Icelandic Sagas.}

means of decision. Then if he decided for Christianity, the pagans could not think themselves injured; though as a matter of fact they did, which is the usual result of arbitration.

The tale of Thorstein Oxfoot, told in Olaf Tryggvason's Saga, supplies another example of divination by dreams. At harvest Thorstein with one companion, Freystein, went to a great howe, and told his companion not to waken him however troubled his sleep should be. He dreamt that the howe opened, and he saw eleven sitting on one side and twelve on the other; they gave him tokens for which be uttered no thanks, and prophesied the future to him.

\section{Feasts and Sacrifice.}

As a rule, the saga-references to festivals are no more definite than the bare statement that a certain man " had a feast in the autumn," or at Yule, and such details as would serve to associate these feasts with any special cult are rare.

I. The Winter Nights, at the close of harvest.

I. (Glsla, 963.) Summer passes and it comes to the Winter Nights. It was the custom of many men to welcome the winter at that time, and to have then feasts and winternights' sacrifice; but Gisli left off sacrifice since he was in Denmark, but kept to the feasts.

2. $(I b, 964)$ Thorgrim meant to have an autumn feast at the Winter Nights, to welcome winter and sacrifice to Frey. They drank in pairs.

3. (Egla, 904) A great feast was prepared, and there was to be a Dlsablot (in Norway; the context shows that this was in the autumn).

4 (Heimskringla, 868.) Many people were at Gaular for the autumn sacrifice. 
II. Yule, at midwinter.

1. (Heimskringla.) There was a midwinter sacrifice at

Upsala; Ingjald ate a wolf's heart and became very fierce.

2. (Ib.) Slaughter-night (Höggu-nótt) was midwinter night, and Yule was kept for three days afterwards. But Hakon the Good made them keep it at the same time as the Christian festival.

3. (Ib.) At the Yule feast the people were sprinkled with the blood of the sacrificed animals, whose flesh they afterwards ate. Toasts were drunk: to Odin for victory and power, to Njörd and Freyja for peace and good seasons; then the Braga-goblet, over which vows were made; and the remembrancegoblet to dead friends.

4 (Svarfdala.) A berserk deferred a challenge till three days after Yule, that he might not violate the "sanctity of the gods."

\section{Midsummer.}

1. (Egla, 917.) There was a great sacrifice at Gaular in the summer. Gunnhild proposed to kill Skallagrim's sons there, of whom Thorolf was to sacrifice to learn his and Egil's luck. All men were unarmed; and Eyvind, one of the attackers, was outlawed for "slaying in sanctuary," a common phrase in the sagas.

2. (Landnama, 900.) Lopt went every third summer from Iceland to Gaular to sacrifice for himself and his mother's brother at the temple which his mother's father had kept at Gaular. (This looks like some local cult.)

Heinskringla says of the three sacrifices that "towards winter there was blood sacrifice for a good year, and in midwinter for a good crop, and in summer for victory," though the other reference quoted above from the same 


\section{Custom and Belief in Icelandic Sagas.}

makes the Yule sacrifice include all. If the Dhablbt were really held in late autumn, it would indicate that the underworld rites did form a part of the Winter-Nights' feast, which is supported by the last-quoted reference if blood-sacrifice is there meant to be contrasted with firesacrifice; and the remembrance toast at Yule further confirms the view that the dead were propitiated in winter, not in spring. The sacrifice to Frey was in the autumn too, and it is natural and usual to find propitiation of the dead and sacrifice to gods representing the productive and quickening power, occurring at the same season, when the main object of both was to protect the crops. In Roman religion both were in the spring, in the North in late autumn. The reason may lie in the different circumstances of their agriculture. Another possibility is that a northern winter was such a serious thing, that the Northerners might naturally think of its beginning, when the days are visibly shortening, as the dangerous time.

Sacrifice seems to have been generally of animals in the saga-time, and human sacrifice was only proposed in special emergencies. In the reign of the mythical King Domald (Heimskringla), when there was famine, "in the first year they sacrificed animals; in the second year, men; at last, the king," which is a case of reversion to human sacrifice and at the same time a trace of the "Golden Bough" theory of kingship. The latter receives further support from Hcimskringla:

1. (Ynglinga Saga.) The Swedes used to reckon good or bad crops for or against kings. They said Olaf was sparing in sacrifice, and burnt him in his house as a sacrifice to Odin for the crops.

2. (Halfdan the Black's Saga.) King Halfdan was highly regarded because he was most fortunate in good seasons. All the people of Norway wanted to have him buried in their own districts, to ensure 
good crops. At last his body was divided into four parts, which were buried in Ringerige, Raumarige, Westfold, and Hedemark : a mixture of the local cult of a hero's tomb with king-sacrifice to induce fertility.

In connexion with this point must be noticed the anxiety of the people that the Christian King Hakon should offer sacrifice for peace and a good year, as his fathers used to do.

Another mythical king, Ón, in Ynglinga Saga, sacrificed his sons to Odin for long life, apparently that he might have the years they had not lived.

In Iceland, the saga-writers state (Eyrbyggja) that in their day "the doom-ring is still seen where men were doomed to sacrifice, and Thor's stone, on which men were broken for sacrifice." Before the end of the first half of the tenth century, that is to say, within a few years of the completion of the settlement, it was no longer customary, for it is mentioned in the Waterdale Saga (about 936) as a matter of hearsay only: "Thorolf Heljarskin had sacrificial dens, and people thought he sacrificed both men and cattle." As late as 970 we find a proposal to revive it in a special emergency; in an unusually hard winter, the Reykdale priest proposed that men should vow to give to the temple, expose children, and kill old men. Askell objected, and though many opposed him, carried the day, and all who were reasonable thought he spoke well.

The test of paganism on the establishment of Christianity in the year 1000 was the eating of horseflesh. According to the account in Njala, it was forbidden, together with idolatry and the exposure of children, while sacrifice was to be allowed in private, though a man was subject to outlawry if the matter became known. Kristni Saga says the eating of horseflesh was allowed at first. Yet the custom is very seldom mentioned, and that only 


\section{Custom and Belief in Icelandic Sagas.}

casually. This is to be expected : the more customary a practice is, the less is it likely to be specially recorded.

1. Heimskringla. That the king should partake of the sacrificial horseflesh in some form or other, is the one point on which Hakon the Good's subjects refused to give way.

2. (I6.) In the account given of the temple ritual, it is said that the blood "of cattle as well as horses" was sprinkled on the walls and the people, and the flesh then eaten.

3. (Eyrbyggja, early tenth century.) Thorbjörn Digri had many stud horses, and used to choose a horse to be slaughtered in the autumn.

4. (Reykdala, 970.) It is proposed that there be a horse-fight at Mánahjalli at midsummer; Thorkell Geirason of Skaro had a grey horse with a different coloured mane, and he and his father always gave a horse for slaughter, but had no mind for horsefighting.

The exact significance of the horse is a matter of question. We may compare the Roman Equiria in February, and the sacrifice of the "October horse" on the Ides of October, and the dripping of the blood on the sacred hearth. Mannhardt identifies the horse with the vegetation spirit, and it is evident from the scanty material in the sagas that it in some way represented a principle of life. It was sacrificed in the autumn and at Yule, at both of which festivals there were agricultural rites.

The favourite Icelandic sport of the horse-fight was most probably connected with the festivals. The quotation from Reykdala suggests that some practice may have existed of sacrificing the winner, which would account for the reluctance of the Skard chiefs to let their horses fight. 


\section{Custom and Belief in Icelandic Sagas. 421}

VII. Magic.

The belief in the practice of magic was general in Iceland at the time of the saga-writing. There is much sameness in the spells; and the frequency with which the same names occur seems to suggest that in many cases the sorcery was a conventional incident. Even so, however, there must be some basis of tradition. The best sagas contain incidents of the kind. In some cases the sorcery is connected with sacrifice, though this may be a late attempt to discredit pagan ritual; in others the spells are of an imitative kind. While those who practised divination were respected and respectable, those who practised sorcery were not, though many had recourse to their help. The combatants in a duel often applied for help to a sorceress, who could make a man wound-proof, or blunt the edges of his adversary's sword; sometimes the spells affected the inclinations or desires, or the destiny of a man; rain-spells and other weather-charms are of frequent occurrence. The spell could be rendered ineffective if the sorcerer were watched. Those who possessed magic powers are called fjölkunnigr (fjöl, much; kunnigr, wise), and hamramr (shape-shifting, from kamr, a shape); and the power of changing shape, as well as that of casting illusions, belonged to them.

\section{Shape-shifting.}

This is sometimes represented as genuine change of form, sometimes as the result of a glamour thrown over bystanders. The origin of a name is attributed to it certainly in one, and possibly in two instances:

1. (Harbar Saga, 950.) Björn Blasior was the son of Ulfhétin, son of Ulfhamr, son of Ulfr, son of Ulfhamr the shape-shifter.

2. (Egits Saga, 825.) Ulf's custom was to rise early ... Every evening he became bad-tempered, so 


\section{Custom and Belief in Icelandic Sagas.}

that few could get speech with him; he was fond of evening sleep. People said he was hamramr, He was called Kveldulf (evening-woln)

3. (Thorskfirtinga, 930) Askmazr and Katla escaped as swine. Thori killed one, and found it was Askmatr, but Katla got away.

4 (Ib.) Thurid in the form of a sow got in Kerling's way.

5. (Hartar Saga, 95a) "It is no good to Hord if the saying is true that men are like their mother's brothers, for thou art not cinhamr" (of one shape).

6. (Kormak's Saga, 959) Kormak wounded a walrus; they thought it had Thorveig's eyes. She lay ill after that, and some said she died of it.

7. (Laxdala, 960.) A seal was seen in the water going in a circle round the ship, much bigger than others. . . . It seemed to all to have a man's eyes. Thorstein bade them shoot it; they failed, and the ship was wrecked and all drowned but one.

8. (Hoensa-Thori's Saga, 964) Thorbjörn "was not always all where he was seen."

9. (Eyrbyggja, 970-80.) Katla saved her son Odd from his enemies by disguising him first as a distaff off which she spun yarn; then as a goat; then as a hog; until they brought another sorceress, Geirrid, against whom glamour could not. prevail.

10. (Harbar Saga, 980.) Hord's companions were attacked by a bull, on the farm of Thorstein, whose fostermother, Skroppa, was a witch. He advised them to be careful because "All is not here as it seems." .. . They saw a sow and two pigs north of the garth; and a band of armed men. They killed the sow with a stone, and there lay Skroppa dead, and Thorstein's two daughters stood beside her, and the men were a herd of cattle. 


\section{Influence on desires or fate.}

I. (Egils Saga, 934) Gunnhild had spells performed, that Egil should never rest quiet in Iceland till she should see him.

2. (Kormak's Saga, 957.) Kormak stopped desiring the match, because Thorveig wrought a spell (The sequel is given in a later quotation from the saga, under the fourth section.)

3. (Gisla Saga, 964) Borrk gave Thorgrim Nef an ox nine years old to make spells, that Thorgrim's slayer might not remain hidden.

4. (Waterdale Saga, 975.) Thordis the prophetess bade Thorkell go in her black coat, and strike Gudmund three times on the left cheek with her staff, to make him lose his memory; and later, three times on the right to bring memory back.

\section{Blunting Swords.}

I. (Thorskfirbingu, 930.) Askmarr blew on the edges of Mar's sword, that it should not bite.

2. (Ib.) Kerling looked at the sky between her feet, that Thori's weapons might not bite.

3. (Waterdale Saga, 936.) Thorgrim Skinnhufa used to blunt swords.

4 (Fljitsdala Saga, 998.) Gauss knew how to blunt swords.

\section{Protection against wounds.}

In Kormak's Saga, between 930 and 965, there are several examples of charms wrought for this purpose:

r. Helga's fostermother touched men before they went to battle; she did so to Ogmund, and he said he felt no great wound; the sword did not bite him.

2. Thorveig gave Bersi a small iron-rimmed shield to make him wound-proof. 


\section{Custom and Belief in Icelandic Sagas.}

3. Thordis the prophetess made Thorvard wound-proof before his combat with Kormak. The latter was sent by his mother to obtain help for the same combat. Thord's told him he came too late, but if he stayed the night she would make him woundproof too. In the night he felt a touch on his head, and followed to the door; she had gone to the place where they were to fight, and had a goose. She said: "Why could you not be quiet?" He lay down again and the same thing happened three times. The third time, she had killed two geese and let the blood run into a bowl; then she had taken the third goose and was going to kill it He said "What good will that do, fostermother?" and she said there was no helping him: "I thought to take off the ill-luck which Thorveig laid on you and Steingerd, and you might have been happy if I had killed the third goose unknown to anyone" They went to the combat: Thorvard gave the prophetess more money and received the sacrifice (obscure). She told Kormak she could cause Thorvard not to know him ; but Kormak spoke ill to her, and said she would do nothing but harm, and tried to drag her out of doors and see her eyes in the sunshine, but his brother prevented him. In the combat the swords did not bite.

Thordis, as prophetess (spdkona), is not represented as intentionally mischievous, like Thorveig and Katla She is a wise-woman, not a witch.

\section{Weather Spells.}

1. (Thorskfirtinga Saga, 930) Kerling had a cap of darkness over the ship.

2. (Waterdale Saga, 936.) Ljot walked backwards with her head between her legs. She said she had meant to turn the land upside down, and they 


\section{Custom and Belief in Icelandrc Sagas. 425}

would have run mad with the wild beasts, if they had not seen her before she saw them.

3. (Ib.) Helga said she would prevent the combatants from going to a duel. There was great frost and snow.

4. (Waterdale, 955.) Groa invited Thorstein to her house. He was three times warned in a dream not to go. A shepherd saw her go widdershins round the house after sunset, and say "It is difficult to withstand the luck of Ingimund's sons." Then she went up on the fell and waved a handkerchief with much gold tied up in it, and said "Now let what is prepared go." There was a landslip on the farm.

5. (Harbar Saga, 959.) Thorbjörg Katla knew that a ship was come. Then she sought her hood, and waved it over her head, and great darkness came over Geir and his men.

6. (Gisla Saga, 965.) Aub̌bjorg went several times widdershins round the house, and scented in all quarters and lifted her nostrils. The weather changed, and there was a snowstorm, and thaw, and a snowslip on Berg's farm. It was the death of twelve men, and the mark is there to this day.

7. (Njals Saga, 970) Svan waved a goatskin over his head to cause mist.

8. (Waterdale Saga, 98I.) To stop a storm, Styrfinn told the men to make a ring hand in hand; then he went thrice widdershins, and spoke Irish, and bade them say "yes" to him; then he waved a handkerchief to the fell, and the storm ceased.

9. (Njala, 998.) Galdra-Herinn (Herinn of the Spells) held a sacrifice to bring disaster on the missionary Thangbrand. The earth swallowed Thangbrand's horse, but he himself was saved. 


\section{Custom and Belief in Icelandic Sagas.}

In the majority of these cases the spells are magic pure and simple, with no suggestion of origin in religious rites of any kind. The exception is the passage which is most certainly authentic, that from Kormak's Saga. The frustration of a spell by interference or observation is illustrated by this passage and by Ljot's spell in the Waterdale; apparently also by a corrupt passage in Hoensa-Thori's Saga: Thorbjörn wishes to cause Herstein's cattle to come safely out of the outhouses on the burnt farm, and tells him, "Be silent if thou canst, whatever happens." That danger attached to observation by an outsider is suggested by an incident in Laxdala, where Kari is killed through looking out while Kotkell is conducting spells.

It will be seen that as regards religion the material is not extensive; but this fact proves, if it proves anything, exactly the opposite of what several Norse scholars try to make it prove. Just because two gods only are named in the sagas as receiving sacrifice, the argument from omission is worthless. If no sacrifice to Odin, Freyja, Frigg, is ever recorded in the sagas, no one is justified in assuming, as Dr. Bugge for example does, that because Balder is never mentioned in the sagas, therefore he was not an ancient god. The records of Scandinavian paganism are the very reverse of the Roman, where myth is scanty, and custom and ritual abundant. The Scandinavians had only three great feasts in the year, where the Romans had as many in a month. Thus the saga material confirms Cæsar's reference to the religion of the Germans, "neque student sacrificiis;" and the small number of recorded sacrifices rests not on the decay of paganism before the establishment of Christianity, nor altogether on its suppression afterwards, but on a natural race distinction.

I. WinIFred Faraday. 